KATARZYNA POTYRAŁA

Uniwersytet Pedagogiczny im. Komisji Edukacji Narodowej

Forum Pedagogiczne

Kraków

LIGIA TUSZYŃSKA

Akademia Pedagogiki Specjalnej im. Marii Grzegorzewskiej

2016/2 cZ. 2

Wpłynęło: 15.05 .2016

Zatwierdzono do druku: 26.10 .2016

DOI: 10.21697/fp.2016.2.32

Warszawa

\title{
ANIMATORZY LOKALNI JAKO NOWA ŚCIEŻKA ROZWOJU ZAWODOWEGO NAUCZYCIELI PRZYRODNIKÓW
}

\begin{abstract}
Streszczenie: Pedagogiczne refleksje nad konstruowaniem i wspólną negocjacją świata przez jednostki na podstawie doświadczenia i relacji społecznych są istotnym elementem włączania i rozwijania idei pedagogiki partycypacyjnej (Naumiuk 2014, s. 25). W tym celu należy odejść od modelu kształcenia skoncentrowanego na podziale ról na nauczyciela (tego, który naucza) i ucznia (tego, który jest uczony) oraz na ekspertów i nowicjuszy. Punktem wyjścia powinna być aktywność obu stron w procesie zdobywania i pogłębiania wiedzy, a dopiero potem dzielenie się wiedzą, budowanie sieci osób aktywnych i wspólne działania (Potyrała 2016, s. 276). Przyroda jest znakomitym laboratorium i miejscem badań, a obserwacja i obcowanie z nią podpowiadają nam, jak zdobywać wiedzę, pracować w grupie, chronić przyrodę i zachowywać się w jej środowisku (Korwin-Szymanowska i in. 2015, s. 9-36). Celem artykułu jest ukazanie możliwości poszerzenia oferty edukacyjnej w zakresie rozwoju zawodowego nauczycieli przyrody oraz przedstawienie teoretycznych założeń nowych tendencji edukacyjnych wraz z propozycjami ich wdrożenia do praktyki akademickiej.
\end{abstract}

Słowa kluczowe: animator, środowisko lokalne, edukacja przyrodnicza, kształcenie nauczycieli

\section{Potrzeby i założenia praktyki animacyjnej w środowisku lokalnym}

W Polsce w okresie transformacji społecznej ujawniła się potrzeba zwrócenia uwagi lokalnych społeczności na sprawy własnego środowiska oraz tworzenie lub zachowanie specyfiki kulturowej danego regionu. Pojawiły się problemy związane $\mathrm{z}$ danym środowiskiem, $\mathrm{z}$ degradacją i dewastacją przyrody na terenie lokalnym. Wiele z nich, niecierpiących zwłoki, trzeba było rozwiązywać własnymi siłami.

Reforma systemu edukacji w 1999 roku, w odpowiedzi na zapotrzebowanie społeczne, wprowadziła do podstawy programowej kształcenia ogólnego dydaktyczne 
ścieżki międzyprzedmiotowe nazwane edukacją ekologiczną i edukacją zdrowotną. Cele i treści kształcenia szkolnego miały koncentrować się wokół ochrony środowiska i zdrowia człowieka. Jednak poziom świadomości społeczeństwa w tym zakresie, szczególnie w lokalnych środowiskach, wśród mieszkańców dzielnic dużych miast i małych miejscowości zwiększał się zbyt wolno. Drwiny z „czynów społecznych" będących chlubą socjalizmu spowodowały, że początkowo wszelkie działania społeczne, jak też zajęcia pozalekcyjne w szkołach uległy stagnacji. Po pewnym czasie coraz więcej ludzi zaczęło jednak odczuwać naturalną potrzebę działania na rzecz środowiska lokalnego. Odpowiedzią na to stały się ruchy obywatelskie, które jednak, jak słusznie zauważyła Agnieszka Naumiuk (2014, s. 8), zbyt często samoistnie zaczęly wchodzić w postmodernistyczną grę interesów, zaniedbując refleksję nad swoją genezą i szerszym kontekstem podejmowanych działań.

W następstwie wydania aktów prawnych, m.in. Ustawy z dnia 16 kwietnia 2004 r. o ochronie przyrody, w jednostkach samorządowych utworzono komórki odpowiadające za ochronę środowiska i edukację $\mathrm{w}$ tym obszarze. Wydziały ochrony środowiska zostały zobowiązane do przedstawiania na stronach internetowych własnych strategii i programów ochrony środowiska. $Z$ analizy tych programów, jak podaje Ligia Tuszyńska (2008), wynika, że w olbrzymiej ich części edukacja ekologiczna społeczeństwa została scedowana na lokalne szkoły bez wyjaśnienia, jaka ma być ich rola. Tylko niektóre gminy zatrudniają liderów czy animatorów ochrony zdrowia i środowiska człowieka. Zaniechano przy tym tworzenia konsekwentnej koncepcji wychowania środowiskowego oraz podejścia badawczego o charakterze diagnostyczno-eksploracyjnym, które mogłoby wspierać praktykę animacyjną.

Koncepcja działań społecznych, oparta na „dokonywaniu zmian, mobilizowaniu jednostek i środowisk do wysiłku przekraczania tego, co zastane, ku realizacji marzeń, co i jakie być powinno, nie jest nowa, zwłaszcza na gruncie pedagogiki społecznej, lecz warta mierzenia się z jej współczesnymi reinterpretacjami” (Naumiuk 2014, s. 7). Analizując różnorodne praktyki animacyjne, można stwierdzić, że wyrastają one głównie z potrzeb natury pragmatycznej, społecznej lub intelektualnej danej społeczności (Kruczkowska, Stano 2013). Trzeba przy tym podkreślić, że popularyzacja nauki odbywa się przede wszystkim $\mathrm{w}$ ramach edukacji nieformalnej, która wspiera popularyzację wiedzy (Raichvarg i in. 2015). Należy też przyjąć określoną koncepcję kultury naukowej w związku z konkretną praktyką upowszechniania nauki i popularyzacji wiedzy (wpisującą się w profil zawodowy animatora kultury przyrodniczej).

Kultura naukowa prowadzi do stawiania pytań o społeczeństwo i nie skupia się tylko i wyłącznie na sferze wiedzy (Canguilhem 1961). Może obejmować zarówno wiadomości, jak i umiejętności rozumienia i kojarzenia, które umożliwiają myślenie i efektywne działanie umysłu (Raichvarg, Jacques 1991). Kultura naukowa jest przede wszystkim pewnym stanem mentalnym, sposobem stawiania pytań światu, rodzajem myślenia, widzenia, analizowania (Giordan, Pellaud 2009). Żadna 
edukacja, poza przekazywaniem wiedzy, nie może się obyć bez jednoczesnej głębokiej refleksji, która leży u źródła wiedzy, na temat jej roli w społeczeństwie, oraz bez krytycznej oceny ograniczeń tejże wiedzy i jej rzeczywistego statusu w społeczeństwie (Fouchereau 2012). Animator społeczny w zakresie kultury naukowej to zawód stawiający przed osobami, które go wykonują, odpowiedzialne zadanie łączenia popularyzacji wiedzy z pogłębianiem własnych wiadomości na temat społeczności lokalnej i środowiska lokalnego w kontekstach potrzeb edukacyjnych.

Celem niniejszego artykułu jest zwrócenie uwagi na nową możliwość, jaką staje się ścieżka rozwoju zawodowego nauczycieli przyrodników, polegająca na sprawowaniu funkcji animatorów kultury przyrodniczej dla społeczności lokalnych. W roku akademickim 2014/2015 na Uniwersytecie Pedagogicznym w Krakowie, we współpracy z Uniwersytetem Burgundzkim w Dijon (Francja), w ramach projektu współfinansowanego ze środków Unii Europejskiej (Europejskiego Funduszu Społecznego), na kierunkach biologia i ochrona środowiska utworzono specjalność animacja kultury przyrodniczej. Zarówno nauczyciele akademiccy, jak i studenci nowej specjalności mieli możliwość korzystania z polsko-francuskich doświadczeń oraz wsparcia merytorycznego w postaci literatury zagadnienia i badań naukowych prowadzonych przez partnerskie uczelnie.

\section{Animacja społeczna jako strategia pracy środowiskowej}

Pytanie kluczowe z punktu widzenia animacji społecznej w zakresie wiedzy o środowisku oraz kształtowania postaw społecznych względem środowiska naturalnego jest związane z poszukiwaniem sposobów udostępniania wiedzy oraz budowania relacji wychowawczej w środowisku. Brzmi ono: jakie metody kształcenia może stosować animator $\mathrm{w}$ perspektywie społecznego dialogu z nauką i popularyzacji wiedzy?

Podstawową koncepcją edukacji opartej na partycypacji społecznej jest konstruowanie świata w działaniu, a konkretnie konstruowanie rzeczywistości w życiu codziennym - interpretacja świata przez język, wytwory kultury, instytucje. Współczesny świat korzysta $\mathrm{z}$ teorii konstruktywistycznych w związku z negacją radykalnych spojrzeń i kwestionowaniem pewników jako uniwersalnych odpowiedzi na pytania o to, jaki jest człowiek i świat (Naumiuk 2014, s. 22), a pedagodzy podnoszą kwestię potencjału emancypacyjnego, twórczego i dynamicznego ludzkiego umysłu, woli i działania w opozycji do deterministycznych ujęć wpływania rzeczywistości na kształtowanie naszej świadomości (tamże, s. 23).

Zarówno świadomość, jak i postawa są pojęciami definiowanymi przez nauki społeczne. Z punktu widzenia pedagogiki świadomość, w odniesieniu do przyrody nazywana również świadomością ekologiczną, stanowią wiadomości, umiejętności i postawy wobec środowiska. Pod pojęciem postawy ekologicznej rozumiemy zaś motywację i bezinteresowne działania na rzecz środowiska, dające się zbadać (zmierzyć) metodami naukowymi. 
Ustawa z dnia 24 kwietnia 2003 r. o działalności pożytku publicznego $i$ wolontariacie głosi, że inicjatywa lokalna to forma współpracy jednostek samorządu terytorialnego z mieszkańcami w celu wspólnego realizowania zadania publicznego na rzecz społeczności lokalnej. Działalność ta może obejmować szereg przedsięwzięć m.in. z zakresu: porządku i bezpieczeństwa publicznego, ochrony przyrody, edukacji, oświaty, wychowania, działalności w sferze kultury fizycznej i turystyki. Są one szansą dla człowieka na podniesienie poziomu świadomości ekologicznej i kształtowanie postaw obywatelskich, a dla społeczeństwa na zrównoważony rozwój.

Ukształtowanie postaw obywatelskich powoduje, że zwiększa się uczestnictwo członków danej społeczności w życiu publicznym, co z kolei przekłada się na ich aktywność na rzecz rozwoju lokalnego. Jej istota w tym znaczeniu sprowadza się do tego, że członkowie lokalnych społeczności poprzez aktywny udział w życiu publicznym sprawiają, że w danym miejscu podnosi się jakość życia, zwiększa poziom sprawności rozwiązywania problemów regionalnych oraz realizacji celów rozwojowych w porównaniu ze społecznościami lokalnymi, których członkowie nie partycypują $\mathrm{w}$ działaniach lokalnych. W związku $\mathrm{z}$ tym, jak podaje autor Koncepcji animacji lokalnej $w$ projekcie liskowskim Tomasz Kaźmierczak (2008), podejmowanie animacji jest szczególnie preferowane w społecznościach biernych, zacofanych oraz zaniedbanych.

Animacja to również obszar praktyki, która polega na wspieraniu działających $\mathrm{w}$ społeczności lokalnej grup oraz na udzielaniu pomocy w tworzeniu nowych inicjatyw, które zainicjują aktywność w życiu lokalnej społeczności.

Animacja w zakresie edukacji ekologicznej społeczeństwa pozwala na badanie zjawisk przyrodniczych w celach poznawczych (za: Tuszyńska 2006), m.in.:

- wykrywanie zależności pomiędzy poszczególnymi grupami zjawisk i organizmów,

- prowadzenie obserwacji zjawisk zachodzących w przyrodzie oraz pojedynczych organizmów,

- poszukiwanie przyczyn istnienia pewnych zjawisk przyrodniczych lub zmian zachodzących w środowisku,

- motywowanie do zdobywania wiedzy przyrodniczej i wiedzy o stanie środowiska lokalnego,

- wykształcenie poczucia odpowiedzialności za stan otaczającej nas przyrody,

- rozwijanie gotowości do aktywności prowadzącej do polepszenia stanu środowiska,

- motywowanie do poznania i badania zjawisk zachodzących w przyrodzie i środowisku,

- tworzenie opinii i przekonań, kształtowanie trwałej i pozytywnej postawy względem środowiska.

Lokalna edukacja środowiskowa, wzmacniana przez animatorów będących przyrodnikami, powinna być obecna nie tylko $\mathrm{w}$ ramach spontanicznych akcji, 
ale odbywać się permanentnie, trwać przez całe życie, by podnosić poziom świadomości ekologicznej społeczeństwa i prowadzić do kształtowania aktywnych postaw obywateli (rycina 1.).

Rycina 1. Podnoszenie poziomu świadomości ekologicznej i kształtowanie postawy proekologicznej poprzez edukację

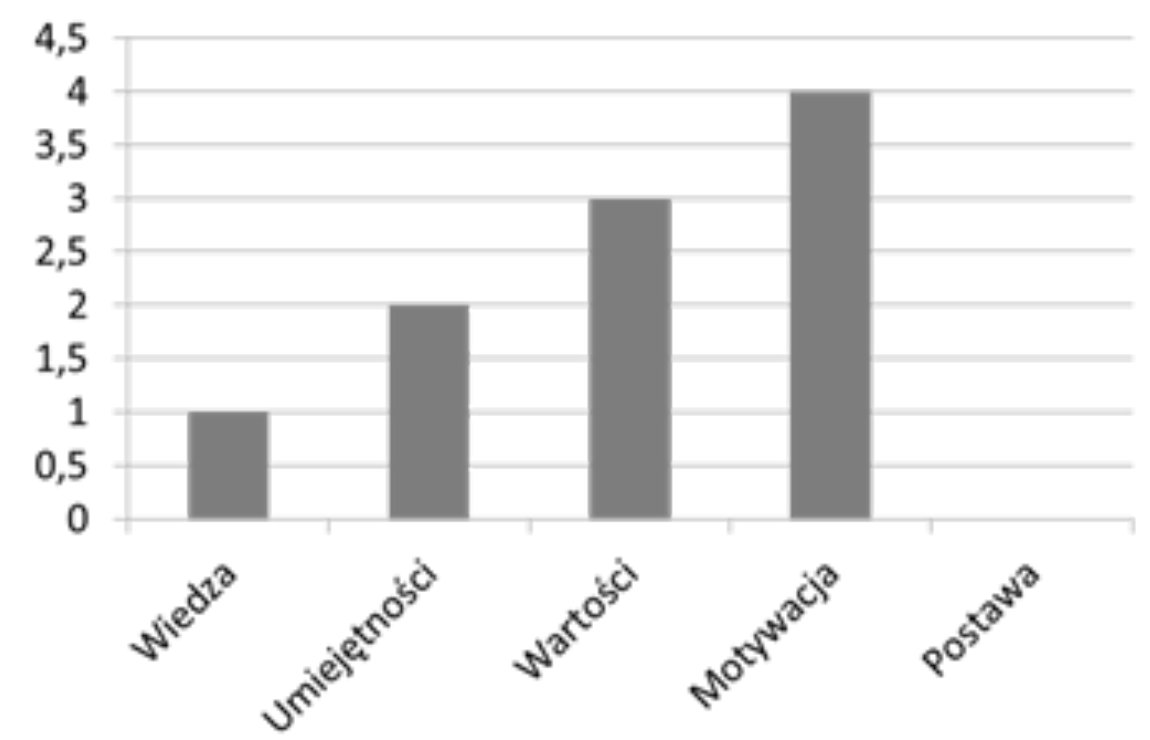

Źródło: opracowanie własne.

Obecna dydaktyka, szczególnie w obszarze nauk przyrodniczych, uczy nas, że w obliczu całości wiedzy naukowej uczący się podaje w wątpliwość swe początkowe wyobrażenia na temat danego zagadnienia. Koncepcje uczących się nie są tylko i wyłącznie odzwierciedleniem obrazów rzeczywistości, lecz służą im również za punkt zaczepienia, potrzebny do przyswajania nowej wiedzy, ponieważ stanowią struktury umożliwiające gromadzenie nowych informacji (Raichvarg i in. 2015, s. 9). Rekonstruowanie i redefiniowanie wiedzy i wyobrażeń o świecie oraz umożliwienie odbiorcom, członkom społeczności lokalnej, stawiania pytań oraz poszukiwania na nie odpowiedzi wpisuje się w model animacji społecznej oraz stosowane przez animatorów metody edukacyjne. Aby informacje naukowe docierały do odbiorców i były przez nich przyswajane, niezbędne jest nadawanie im atrakcyjnej, interesującej formy - muszą budzić zaciekawienie, motywować do poświęcenia czasu i uwagi na zaznajomienie się z ich treścią (Raichvarg i in. 2015, s. 11).

Media, jakie wybierają animatorzy, zależą w dużej mierze od celów, treści i metod kształcenia. Mogą to być na przykład artefaktualne przedmioty, które jednocześnie są przedmiotami kulturowymi w znaczeniu antropologicznym i systemami komunikacyjnymi. Coraz częściej dzisiejsza sztuka angażuje widza, zaprasza go do współuczestnictwa. Skłania już nie tylko do kontemplacji, lecz przede wszystkim 
do wejścia w dialog. Tym samym przestaje istnieć dystans między dziełem sztuki a odbiorcą. Widz zaczyna działać (Raichvarg i in. 2015, s. 66).

Jak pisze Sylwia Słowińska (2013, s. 135), projekt animacyjny to metoda, która ma prowadzić do zmiany (świadomości animatora i uczestników; środowiska; zmiany społecznej), dlatego można go zintegrować z badaniami w działaniu. Jawi się zatem jako przedsięwzięcie trudne, długotrwałe i bardzo absorbujące. Jest jednak propozycją godną uwagi tych animatorów, którzy swoją rolę pojmują w kategoriach ingerowania w rzeczywistość społeczną i zmieniania jej, a nie utrwalania status quo lub pozorowania zmian (tamże, s. 136).

\section{Animator kultury przyrodniczej w środowisku lokalnym - zarys profilu zawodowego}

Rozpatrując koncepcje animacji społeczno-kulturalnej oraz podejmując próbę nakreślenia sylwetki animatora, Zofia Kruczkowska i Bernadeta Stano (2013, s. 30-32) skłaniają się w stronę modelu złożonego z następujących elementów:

1. animator kultury - podmiot, który spontanicznie bądź z racji pełnionej funkcji ożywia środowisko, rozbudza pożądanie wiedzy, wpływa na rozwój różnorodnych zainteresowań, ale też rozumie i docenia wagę nauczania i wychowania w życiu jednostki,

2. działania animatora - reakcja na zdarzenia występujące w danej sytuacji, ale też działania kreacyjne - animator organizuje poszczególne elementy sytuacji i wspólnie $z$ innymi uczestnikami generuje oraz promuje dla nich i dla siebie określone zadania i relacje oparte na wzajemności i podmiotowości partnerów,

3. zadania animatora - budowanie przestrzeni, choćby tylko komunikacyjnej, w której animowani mają prawo głosu, oraz warunków umożliwiających wyrażenie własnej opinii,

4. etos kultury czynnej - „uzewnętrznione rozeznanie i sposób obecności w świecie wartości".

Jak pisze Grzegorz Godlewski (2008, s. 64): „Chodzi o to, aby dla modelu opartego na bierności/odtwórczości/receptywności/zmysłowości stworzyć przeciwwagę w postaci modelu opartego na aktywności/twórczości samorealizacji/wrażliwości poznawczej, aksjologicznej i estetycznej".

Charakteryzując sylwetkę animatora kultury przyrodniczej, trzeba wskazać cechy, których posiadanie niewątpliwie ułatwi mu pracę. Animatorem powinien być praktyk, który zna wartości płynące z przyrody i dostrzega zagrożenia dla niej i zdrowia człowieka. Rola animatora kultury przyrodniczej w kształtowaniu inicjatyw lokalnych związana jest $z$ umiejętnym wykorzystaniem własnej wiedzy i doświadczenia. Za pomocą dostępnych metod, technik i narzędzi potrafi on zainicjować wśród członków społeczności organizowanie się w celu rozwiązywania lokalnych problemów środowiska. Wydaje się pożądane, aby był świadomy 
własnych możliwości i ograniczeń, zarówno fizycznych, jak i psychicznych, i potrafił akceptować siebie oraz innych. Ważną cechą jest również zdolność do życia i funkcjonowania w zbiorowości, jak i umiejętność dostosowania się do uwarunkowań otoczenia. Najważniejszą cechą animatora jest postawa i inwencja twórcza w komunikowaniu się ze społeczeństwem i przedstawicielami samorządu lokalnego, szczególnie w okresie pomiędzy działaniem a pojawieniem się efektu tego działania.

W związku z rolą animatora kultury przyrodniczej w kształtowaniu inicjatyw lokalnych powinien on dysponować:

- znajomością środowiska przyrodniczego w miejscu swoich działań,

- wypracowywaną siecią kontaktów i relacji,

- znajomością profilu społeczności lokalnej - mieszkańców, szkół i instytucji działających w lokalnym środowisku,

- znajomością historii, kultury regionu oraz lokalnych i globalnych problemów przyrodniczych,

- umiejętnością podejmowania wspólnych decyzji poprzez określanie jednego celu działania,

- opracowanym projektem działań w oparciu o dynamikę pracy grup lokalnych (szkoły, koła zainteresowań, organizacji społecznej, samorządu itp.),

- umiejętnością podtrzymywania zaangażowania i motywowania innych do wyszukiwania nieprawidłowości, z którymi należy walczyć w środowisku,

- umiejętnością tworzenia sieci działań pomiędzy grupami, realizacji wspólnych aktywności na rzecz lokalnej przyrody, podtrzymywania kontaktów i budowania więzi oraz zarządzania informacjami o zasobach przyrodniczych lokalnego środowiska.

Cele animacji osiągane są poprzez realizację określonych przedsięwzięć, które zachęcają członków społeczności do działania. Tomasz Kaźmierczak (2008) wyróżnia trzy etapy animacji, które wskazują również na rodzaj kompetencji, jakie powinien posiadać animator:

1. Etap przygotowania - przydatne są: umiejętność nawiązywania relacji ze społecznością, zdobycia zaufania wśród ludzi, pokazania własnej kreatywności, zaaklimatyzowania się w nowym środowisku, nawiązania znajomości z osobami decyzyjnymi oraz zdobycia podstawowych informacji niezbędnych do realizacji podjętego celu.

2. Etap właściwy - niezbędne są: aktywność animatora $w$ realizacji projektu w danej społeczności, koordynacja zadań cząstkowych, zbudowanie grup zadaniowych, które zajmą się realizacją określonych zadań, składających się na projekt animacyjny.

3. Etap końcowy - najtrudniejszy dla animatora, polega na podsumowaniu projektu i stopniowym wygaszaniu swojej obecności po zrealizowaniu celu pracy. Natomiast ważna staje się ewaluacja projektu, w której należy podkreślić mocne strony jego realizacji i wskazać osoby wyróżniające się, aby w ten sposób dać szansę lokalnej wspólnocie na dalsze samodzielne działanie. 
W porównaniu z klasycznym podejściem pedagogicznym specyfika animacji polega nie tylko na edukacji, lecz również na nadaniu treściom nowego znaczenia poprzez stymulowanie wyobraźni. Tworzy się zatem nowe obrazy miejsc, miast, wiedzy poprzez uwydatnienie elementów odkrywanych na nowo przez „animowanych", którzy do tej pory ich nie zauważali lub traktowali je jako zwykłe pozostałości dawnych czasów; w ten sposób miejsca i obszary wiedzy przekształcają się w scenę. Animator umieszcza publiczność w roli czynnego uczestnika rekonstrukcji, a więc bohatera pewnego świata.

W rozważaniach na temat wyzwań zawodu nauczyciela Robert Kwaśnica (1990) wskazuje na sytuacje edukacyjne, które nie podlegają racjonalności instrumentalnej, lecz komunikacyjnej, oraz na fakt, że „tym, od czego zależą cele, metody i środki działania nauczycielskiego, jest definiowanie (dochodzenie do rozumienia) sytuacji edukacyjnej, która za każdym razem jest inna" (tamże, s. 299-30o). Kształtowanie kompetencji współczesnego nauczyciela przyrodnika powinno zakładać istnienie sytuacji edukacyjnych odmiennych od typowo szkolnych i ukierunkowywać go na podejmowanie profesjonalnej aktywności edukacyjnej na przykład w środowisku lokalnym, centrach nauki i muzeach.

\section{Model animacji kultury przyrodniczej jako jeden z instrumentów polityki społecznej i element kształcenia pedagogicznego}

Jak piszą Magdalena Dudkiewicz i in. (2008), w codziennym życiu spotykamy animatorów, którzy są profesjonalistami, wykształconymi i przygotowanymi do podejmowania działań, są to ludzie, którzy za swoją pracę dla społeczności otrzymują wynagrodzenie. Drugą grupę stanowią jednostki wybitne, które wykazując swoją aktywność np. w dziedzinie ochrony przyrody, przyjmują spontanicznie rolę animatora motywującego do działania i inicjującego projekty lokalne. Zarówno jedna, jak i druga forma animacji jest oczywiście bardzo pożądana, jednak w lokalnych środowiskach najczęściej spotykamy się z inicjatywami wychodzącymi od szkół lub lokalnych organizacji. Dlatego niezmiernie ważne wydaje się zwrócenie uwagi na pedagogów, nauczycieli przyrodników, jako grupę najczęściej realizującą projekty przyrodnicze. Przygotowanie zawodowe nauczycieli w zakresie animacji kultury przyrodniczej, prowadzone obok kształcenia przedmiotowego, wydaje się bardzo istotne.

$\mathrm{Na}$ Uniwersytecie Pedagogicznym w Krakowie zajęcia w ramach specjalności animacja kultury przyrodniczej prowadzone były m.in. w ramach przedmiotów: interakcje i platformy komunikacyjne, popularyzacja wiedzy przyrodniczej, podstawy debaty naukowej, mediacja konfliktów przyrodniczych. Ukazały one studentom różne poziomy i formy partycypacji społecznej, ukształtowały umiejętność posługiwania się wieloma technikami komunikacji w kontakcie z różnymi typami odbiorców. Studenci nauczyli się analizować reakcje słuchaczy w celu dostosowywania swoich działań, form i treści prezentacji oraz sposobu wdrażania technik 
animacji pedagogicznej do różnego rodzaju publiczności. Opanowali umiejętność określania treści i form działań kulturalnych, np. konferencji, wystaw, instalacji, przedstawień, filmów, warsztatów, jak również poznali zasady nawiązywania współpracy partnerskiej ze stowarzyszeniami zewnętrznymi przy okazji realizacji opracowywanych przez siebie projektów kulturalnych. Pozwoliło im to również na trenowanie kierowania zespołem i organizowania jego zadań, a także opracowywania programów artystycznych i kulturalnych na potrzeby animacji i prezentacji we współpracy z podmiotami naukowymi i dydaktycznymi. Wykonywane podczas zajęć ćwiczenia miały na celu wytworzenie umiejętności opracowywania strategii komunikacyjnych, koordynacji działań w zakresie środków mediacyjnych i ich wykorzystania oraz rozpoznawania potrzeb zainteresowanych. Istotne okazało się tu również poznanie poszczególnych kategorii publiczności (niepełnosprawni, niedowidzący, osoby starsze, dzieci i młodzież), jej socjologii i typologii, metod przekazywania wiedzy, tworzenia oraz adaptacji narzędzi i programów mediacyjnych, prowadzenia działań promujących określoną ofertę kulturalną oraz obiegów i kanałów komunikacyjnych.

Studenci mieli też możliwość analizowania związków między nauką i sztuką. Poznali różnorodne aspekty sztuk wizualnych oraz informacje z zakresu historii sztuki, przedstawień artystycznych, literatury, nauk humanistycznych i społecznych, jak również przykładowe zbiory instytucji muzealnych, propozycje instytucji kulturalnych, kierunki polityki władz publicznych w zakresie szerzenia odkryć i wynalazków naukowych w społeczeństwie.

Rycina 2. Umiejętności zdobyte przez studentów specjalności animator kultury przyrodniczej

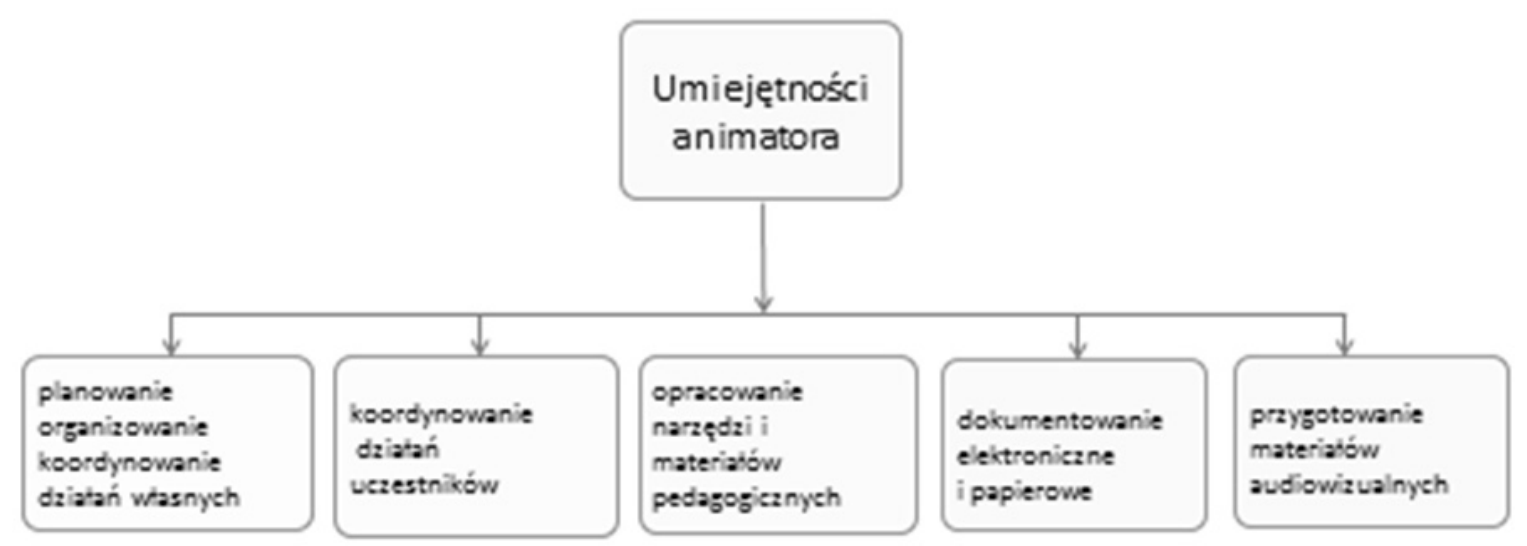

Źródło: opracowanie własne.

Analiza ankiet ewaluacyjnych przeprowadzanych na koniec każdego kursu wykazała, że studenci zauważyli wzrost własnych kompetencji przywódczych, takich jak: umiejętność planowania, organizowania i koordynowania działań swoich 
i „publiczności”; stawianie na zespołowość i zmysł analityczny, ułatwiające negocjowanie z poszczególnymi podmiotami; umiejętność opracowywania narzędzi i materiałów pedagogicznych (dokumentów elektronicznych/papierowych, materiałów audiowizualnych) oraz programów i treści mediacyjnych zapewniających wsparcie dydaktyczne dla wszystkich kategorii odbiorców (rycina 2.).

Podczas ewaluacji studenci przyznali, że zakres kwalifikacji związanych z zawodem animatora poszerzali stopniowo dzięki uczestniczeniu w kolejnych kursach specjalności, stopniowo zwiększało się również ich zaangażowanie społeczne oparte na wartościach humanistycznych. Byli też zdania, że zaszczepienie dobrego „klimatu społecznego" w perspektywie komunikacyjnej to jedno z zadań dobrego animatora, zauważyli to u siebie podczas zajęć, $\mathrm{w}$ ramach których uczyli się mediacji dotyczącej zagadnień edukacyjnych $\mathrm{w}$ aspekcie środowisk miejskich i wiejskich umieszczanych w perspektywie tworzenia wspólnej przestrzeni interpretacyjnej.

Studenci uznali, że posiadają większą niż wcześniej interdyscyplinarną wiedzę z zakresu nauk biologicznych i społecznych (ochrony środowiska, pedagogiki kultury, dydaktyki), co ułatwia im mediację dotyczącą problemów środowiskowych oraz tworzenie projektów z uwzględnieniem różnych odbiorców i współrealizatorów.

\section{Zakończenie}

Zaistnienie i umocowanie animatora w lokalnym środowisku zależne jest $\mathrm{w}$ dużym stopniu od posiadania cech przywódczych i kompetencji. Pomimo dużej popularności takich kierunków studiów jak zarządzanie, politologia czy marketing w praktyce nie potwierdza się teza, że każdy może być przywódcą. Stefan M. Kwiatkowski i Joanna Madalińska-Michalak (2014) wskazują na deficyt dobrych przywódców i zwracają uwagę na potrzebę kształcenia pedagogów w tej dziedzinie. W literaturze wskazuje się przede wszystkim na przywódców takich jak menedżer związany z biznesem, artysta lub polityk. Wydaje się, że szczególnie cenne byłoby przygotowanie pod kątem przywództwa w animacji dotyczącej ochrony środowiska i podnoszenia poziomu kultury przyrodniczej wśród społeczności lokalnych nauczycieli przyrodników. O przywództwie mówimy wtedy, kiedy ludzie dobrowolnie, bez oporu wsłuchują się w zalecenia swojego lidera (animatora), akceptują je i są zmotywowani do podejmowania związanych z tym określonych działań, więc je wykonują (Szymański 2014, s. 240).

Obecna klasyfikacja zawodów i specjalności występujących na rynku pracy nie uwzględnia animacji kultury naukowej/przyrodniczej. Wobec potrzeb społecznych w tym zakresie oraz rozwoju centrów nauki i instytucji zajmujących się edukacją nieformalną, jak również postępujących prac nad określeniem tego zawodu i odpowiadających mu zadań, wydaje się to kwestią czasu. Absolwenci opisanej w artykule specjalności dzięki uzyskanym certyfikatom w zakresie animacji kultury przyrodniczej otrzymali interesujące propozycje pracy w charakterze mediatorów/animatorów muzealnych. Uzupełniające informacje dotyczące wymaganego 
wykształcenia oraz regulacji prawnych tego zawodu w celu jego oficjalnego uznania zgodnie z Międzynarodowym Standardem Klasyfikacji Zawodów będą stanowić przedmiot dalszego zainteresowania autorek.

\section{Bibliografia}

Canguilhem G. (1961). Nécessité de la diffusion scientifique. „Revue de l'enseignement supérieur", nr 3, s. 5-15.

Dudkiewicz M., Kaźmierczak T., Rybka I., Rymsza M. (2008). Animacja lokalna. Jak aktywizować społeczność wiejską. $Z$ doświadczeń projektu „W stronępolskiego modelu gospodarki społecznej - budujemy nowy Lisków". Warszawa: Instytut Spraw Publicznych, s. 6-7.

Fouchereau E. (2012). Didactique des sciences et culture scientifique: quels enjeux pour la formation professionnelle des enseignants? W: Quelle formation pour les enseignants. EUD, s. 171-186.

Giordan A., Pellaud F. (2009). Sciences émergentes: 30 ans de didactique. Nice: Ovadia, Coll. André Giordan Au-delà des Apparences.

Godlewski G. (2008). Animacja i antropologia: następna generacja. W: Kurz I. (red.). Lokalnie: animacja kultury. Warszawa: Instytut Kultury Polskiej UW.

Kaźmierczak T. (2008). Koncepcja animacji lokalnej w projekcie liskowskim. W: Rybka I. (red.). Animacja lokalna i przedsiębiorczość społeczna na rzecz rozwoju obszarów wiejskich. Broszura pokonferencyjna. Warszawa: ISP, s. 19.

Korwin-Szymanowska A., Lewandowska E., Tuszyńska L. (2015). Edukacja środowiskowa w kształceniu nauczycieli w perspektywie praktycznej. Warszawa: APS.

Kruczkowska Z., Stano B. (2013). Artysta nauczycielem i animatorem kultury. Kraków: Wydawnictwo Naukowe Uniwersytetu Pedagogicznego.

Kwaśnica R. (1990). Pytania o psychopedagogiczne kształcenie nauczycieli. W: Kwieciński Z., Witkowski L. (red.). Ku pedagogice pogranicza. Toruń: Wydawnictwo Uniwersytetu Mikołaja Kopernika.

Kwiatkowski S.M., Madalińska-Michalak J. (red.). (2014). Przywództwo edukacyjne -wspótczesne wyzwania. Warszawa: ABC Wolters Kluwer.

Naumiuk A. (2014). Edukacja - partycypacja - zmiana $w$ doświadczeniach i wyobrażeniach działaczy lokalnych (animatorów społecznych). Warszawa: Wydawnictwa Uniwersytetu Warszawskiego.

Potyrała K. (2016). iEdukacja. Synergia nowych mediów i dydaktyki. Kraków: Wydawnictwo Naukowe UP (w druku).

Raichvarg D., Jacques J. (1991). Savants et Ignorants: une histoire de la vulgarisation des sciences. Paris: du Seuil (Sciences).

Raichvarg D., Potyrała K., Di Scala E. (2015). Teatr naukowy, czyli publiczny dyskurs $z$ nauka i popularyzacja wiedzy. Kraków: Libron. 
Słowińska S. (2013). Projekt animacyjny jako metoda pracy w oparciu o badania w działaniu. W: Kubinowski D., Lewartowicz U. (red.). Animacja kultury. Współczesne dyskursy teorii i praktyki. Lublin: UMCS.

Szymański M.J. (2014). Edukacyjne problemy współczesności. Kraków: Oficyna Wydawnicza „Impuls”.

Tuszyńska L. (2008). Diagnoza stanu edukacji środowiskowej społeczności lokalnych $w$ wybranych regionach Polski. Warszawa: WUW.

Tuszyńska L. (2006). Edukacja ekologiczna dla nauczycieli i studentów. Warszawa: WSP-TWP.

Ustawa z dnia 16 kwietnia 2004 r. o ochronie przyrody. Dz.U. 2004, nr 92, poz. 880. Ustawa $z$ dnia 24 kwietnia 2003 r. o działalności pożytku publicznego i wolontariacie, art. 2, ustęp 4 i art. 19b, ustęp 1. Dz.U. 2003, nr 96, poz. 873.

\title{
LOCAL ANIMATORS AS A NEW PATH OF PROFESSIONAL DEVELOPMENT OF SCIENCE TEACHERS
}

\begin{abstract}
Pedagogical reflections on the construction and negotiation of the world by individuals on the basis of experience and social relations are important elements enabling and developing the idea of participatory pedagogy. In order to achieve this we need to move away from the model of education focused on the division of roles for the teacher as the one who teaches and the student - one who is taught, as well as the division into experts and novices. The starting point should be activite participation of both sides in the process of acquiring and improving knowledge, and only then knowledge sharing and networking cooperation. Nature is a great laboratory and a place of research, and its observation and living with it show us how to acquire knowledge, how to work in a group, how to protect nature and how to behave in this environment. The aim of the paper is to show the possibility of expanding the educational offer in the professional development of science teachers and to present theoretical assumptions of the new trends in education as well as the proposals for their implementation in academic practice.
\end{abstract}

Keywords: animator, local environment, science education, teacher training

Katarzyna Potyrała - dr hab., prof. nadzw. UP w Instytucie Nauk o Wychowaniu Wydziału Pedagogicznego Uniwersytetu Pedagogicznego im. Komisji Edukacji Narodowej. Autorka publikacji: The influence of information technology on students' metacognitive competence (2007); współautorka Teatru naukowego, czyli publicznego dyskursu z nauka i popularyzacja wiedzy (2015), Fotografii i dydaktyki (2016); redaktorka Wybranych problemów popularyzacji wiedzy biologicznej i środowiskowej (2012); współredaktorka publikacji: Kreatywny nauczyciel - wskazówki i rozwiazania. Biologia i przyroda (2011), Edukacja przyrodnicza wobec wyzwań współczesności. Podręcznik akademicki (2011), Science Society Didactics (2013), Natura - czlowiek - technologia (2014). Adres do korespondencji: Uniwersytet Pedagogiczny w Krakowie, Wydział Pedagogiczny, Instytut Nauk o Wychowaniu, Katedra Dydaktyk Szczegółowych, ul. Ingardena 4, 30-o6o Kraków. Adres e-mail: potyrala2@wp.pl. 
Ligia Tuszyńska - dr hab., prof. APS w Instytucie Wspomagania Rozwoju Człowieka i Edukacji Akademii Pedagogiki Specjalnej im. Marii Grzegorzewskiej w Warszawie. Zainteresowania: pedagogika zrównoważonego rozwoju, kształcenie nauczycieli, edukacja zdrowotna i ekologiczna w szkole i w społeczności lokalnej. Autorka publikacji: Edukacja ekologiczna dla nauczycieli i studentów (2006), Diagnoza stanu edukacji środowiskowej społeczności lokalnych w wybranych regionach Polski (2008); współautorka Edukacji środowiskowej w kształceniu nauczycieli w perspektywie praktycznej (2015); redaktorka Edukacji środowiskowej w społeczeństwie wiedzy (2010) i Koncepcji zrównoważonego rozwoju w kształceniu nauczycieli klas początkowych (2016). Adres do korespondencji: Instytut Wspomagania Rozwoju Człowieka i Edukacji APS im. Marii Grzegorzewskiej, ul. Szczęśliwicka 40, 02-353 Warszawa. Adres e-mail: ltuszynska@wp.pl. 